\title{
The Rare Trachyandesitic Lavas at Mount Etna: A Case Study to Investigate Eruptive Process and Propose a New Interpretation for Magma Genesis
}

\author{
Gabriele Lanzafame ${ }^{1, *(\mathbb{D}}$, Federico Casetta ${ }^{2}$, , Pier Paolo Giacomoni ${ }^{2} \mathbb{D}$, Massimo Coltorti ${ }^{2}$ and Carmelo Ferlito $^{1}$ \\ 1 Department of Biological, Geological and Environmental Sciences, University of Catania, 95129 Catania, Italy; \\ cferlito@unict.it \\ 2 Department of Physics and Earth Scinces, University of Ferrara, 40400 Ferrara, Italy; cstfrc@unife.it (F.C.); \\ gcmppl@unife.it (P.P.G.); clt@unife.it (M.C.) \\ * Correspondence: gabriele.lanzafame@unict.it; Tel.: +39-0957195746
}

\section{check for}

updates

Citation: Lanzafame, G.; Casetta, F.; Giacomoni, P.P.; Coltorti, M.; Ferlito, C. The Rare Trachyandesitic Lavas at Mount Etna: A Case Study to Investigate Eruptive Process and Propose a New Interpretation for Magma Genesis. Minerals 2021, 11, 333. https://doi.org/doi:10.3390/ $\min 11030333$

Academic Editor: Alexander R Cruden

Received: 26 February 2021

Accepted: 22 March 2021

Published: 23 March 2021

Publisher's Note: MDPI stays neutral with regard to jurisdictional claims in published maps and institutional affiliations.

Copyright: (c) 2021 by the authors. Licensee MDPI, Basel, Switzerland. This article is an open access article distributed under the terms and conditions of the Creative Commons Attribution (CC BY) license (https:/ / creativecommons.org/licenses/by/ $4.0 /)$.

\begin{abstract}
The growth of Mount Etna volcano reflects the superimposition of various eruptive centers, the most voluminous of which is the Ellittico, whose stratigraphic sequence is well exposed on the steep walls of Valle del Bove. The uppermost levels of the sequence have been sampled and investigated through a new set of geochemical data on mineral phases and bulk rock. Sampled rocks display a marked bimodality with aphyric banded trachyandesites, which are some of the most evolved and rare products of the entire Etnean succession $\left(\mathrm{SiO}_{2} 58-60 \mathrm{wt}\right.$.\%), intercalated in plagioclase rich porphyritic mugearites $\left(\mathrm{SiO}_{2} 49-50\right.$ wt.\%, P.I. 35-40). In this paper, we provide a detailed textural, mineralogical, and chemical characterization of these products, providing a new interpretative model for their genesis and significance in the context of the Etnean system. Our approach discusses, in a critical way, the "classic" fractional crystallization model of magmas, not supported by field evidence, and proposes a novel hypothesis in which the aphyric-banded trachyandesites represent be the primary products of a gas-induced partial melting of hypabyssal sills and dykes. This hypothesis represents a step towards a comprehensive description of igneous systems that takes into account not exclusively the evolution of basaltic melts, but also the role of volatile contributions in governing volcanic behavior.
\end{abstract}

Keywords: Mount Etna; partial melting; volatile migration; trachyandesites; banded lavas

\section{Introduction}

Mount Etna is generally viewed as an open conduit volcano in which magma differentiation takes place "en route" to the surface, in a continuous time-space interval comprised between magma arrival at crustal levels and eruption at the permanently active summit craters [1-8]. Rift-related, lateral and sub-terminal eruptions are less frequent, and strictly connected to the tectonic trans-tensional regime affecting the volcano edifice [6,9-11]. The extensional tectonic regime also contributes to maintaining the central main conduits permanently open and a steady-state degassing regime through the summit craters [12]. Magma differentiation at crustal level $(\mathrm{P}<600 \mathrm{MPa})$ is driven by polybaric crystallization of cotectic olivine and clinopyroxene, while plagioclase stability and fractionation are strongly constrained by the magmatic volatiles content in the final $300 \mathrm{MPa}$ of magma ascent $[8,13,14]$. For these reasons, the composition of the products erupted during the last two phases of Mount Etna activity, named Ellittico (57-15 ka) and Recent Mongibello (15 ka to present) are generally very homogenous and relatively poorly differentiated, from hawaiitic to trachybasaltic lavas [15-19]. However, the stratigraphic records show that sporadically Mount Etna volcano has erupted banded lava flows of relatively acidic (i.e., trachyandesitic) composition.

In this study, a detailed petrographic, geochemical, and textural investigation of an entirely preserved 30-m-thick sequence of mildly to more siliceous products enabled us to 
investigate the processes taking place in the plumbing system of Mount Etna during one of the most productive and explosive phases of its evolution [20]. Whole-rock, mineral phase analyses, scanning electron microscopy (SEM) and synchrotron X-ray microtomography characterizations were coupled with mass balance models to simulate the genesis of evolved products at Mount Etna and speculate on the role of volatiles during such episodic events. Results provided new hints on the behavior of the plumbing system of Mount Etna, with general implications in the comprehension of open-conduit volcanoes.

\section{The Ellittico Volcanic Center}

The morphology of Mount Etna owns its impressive look mostly to the remains of the Ellittico edifice [21,22], whose lava flows and tephra crop out extensively on the NW and NE sectors of present-day Mount Etna forming its morphologic backbone. The name Ellittico derives from the elliptical shape $(2 \mathrm{~km}$ major axis and $1 \mathrm{~km}$ minor axis) of the caldera rim remained after the collapse associated with the production of the BiancavillaMontalto ignimbrites during Plinian eruptions [23], which marked the end of the Ellittico phase. Radiometric dating of lavas from flows referred to as the last activity preceding the caldera collapse indicates an age of $14.5 \mathrm{ka}$ [24]. The post-caldera activity took place from a volcanic center essentially coaxial with the Ellittico. As a result, the caldera was completely filled, forming the flat areas around the summit craters and thereafter the present summit craters cones [21].

The Ellittico sequence crops out mainly on the eastern sector of the volcano, on the steep western wall of the Valle del Bove. In particular, it can be fairly well studied along the ridge of Serra Giannicola Grande in the central section of the western wall of the Valle del Bove; here the sequence makes, with its $470 \mathrm{~m}$ of thickness, the upper two-thirds of the ridge. The succession overlies the topmost breccia of the Trifoglietto formation at $2230 \mathrm{~m}$ a.s.l. [25]. The basal portion of the sequence is constituted by a $100 \mathrm{~m}$ thick sequence of lava flows (thickness of single flows $\sim 5 \mathrm{~m}$ ). Here, lavas are generally sub-horizontal, except for the thin layers (thickness $1 \mathrm{~m}$ ) belonging to a small parasitic cone developed on the flank of the Ellittico center. At about $2330 \mathrm{~m}$ a.s.l., the sequences are composed of a series of lava flows 3 to $5 \mathrm{~m}$ thick, interbedded with thick (up to $15 \mathrm{~m}$ ) volcanoclastic layers, for a total thickness of about $200 \mathrm{~m}$. The thicker deposits have a general lenticular shape pinching rapidly out, the distribution of the clasts in the deposit is generally chaotic and does not show evident internal structures being poorly sorted; when present, the sorting is inverse. The juvenile fraction is represented by dark, vesiculated scoria. Free crystals of pyroxene (augite) are also sparsely present. The general appearance of the deposits indicates that they have a fall origin and that there must have been a considerable explosive activity during the eruptive phenomena.

The topmost portion of the ridge is constituted by $170 \mathrm{~m}$ of lava layers with thickness ranging between 1 and $8 \mathrm{~m}$, generally, plagioclase-phyric, with interbedded in the uppermost $50 \mathrm{~m}$ some layers of aphyric lavas. At the very top of the Serra Giannicola ridge at $2680 \mathrm{~m}$, there is the angular unconformity marking the end of the Ellittico succession and the beginning of the recent Mongibello. An extensive sampling of lavas of the Ellittico sequence has been performed along several ridges cropping out on the western and northern walls of the Valle del Bove. More than 200 analyses of the Ellittico products [26] have demonstrated the general geochemical uniformity of the sequence, with the "strange" presence of the aphyric trachyandesite in the uppermost level of the sequence, also on the ridge of the Pizzi Deneri and on the ridge of Punta Lucia [21]. However, the only place where sampling of the aphyric products can be carried out with good stratigraphic control is along the uppermost section of the western wall of Valle del Bove. The western wall starts from the floor of the Valle del Bove at ca. $1850 \mathrm{~m}$ to reach the $2750 \mathrm{~m}$ of Piano del Lago. Along the $900 \mathrm{~m}$ of the western wall of the Valle del Bove, lava and tephra strata are piled up to form sub-horizontal layers which are eroded in steep ridges spaced by gullies and couloirs covered with epiclastic material. Here, we sampled a sequence made by the superposition of 13 lava flows (Figures 1 and 2). The base of the section is given by a 3-m 
plagioclase-rich lava flow (CIC1) locally named "cicirara" for the chickpea-like appearance of plagioclase phenocrysts within [27], followed by 2-m aphyric highly vesiculated lava (FOAM1). The sequence continues with a succession of trachyandesitic lava flows having a thickness of $15 \mathrm{~m}$, from which six samples were collected (TR1 to TR6 from bottom to top with a sampling step of about $2 \mathrm{~m}$ ). These lavas are covered by two thin highly vesiculated lava flows (FL1 and FL2) and a "cicirara" layer (CIC2). The sequence is then topped by two mugearitic lavas (MUG1 and MUG2).

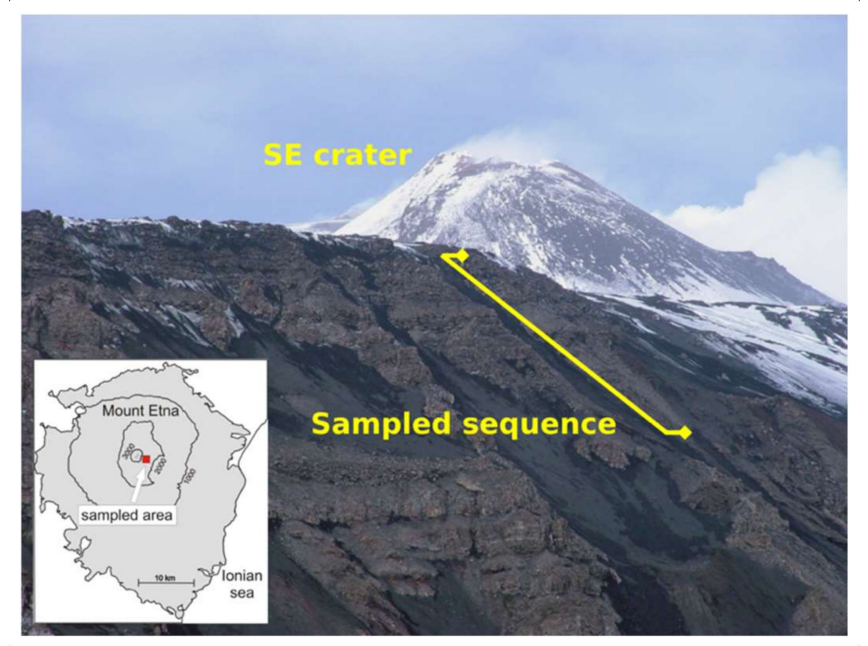

Figure 1. View of the sampled volcanic sequence outcropping in the uppermost part of the western wall of the Valle del Bove at Mount Etna.

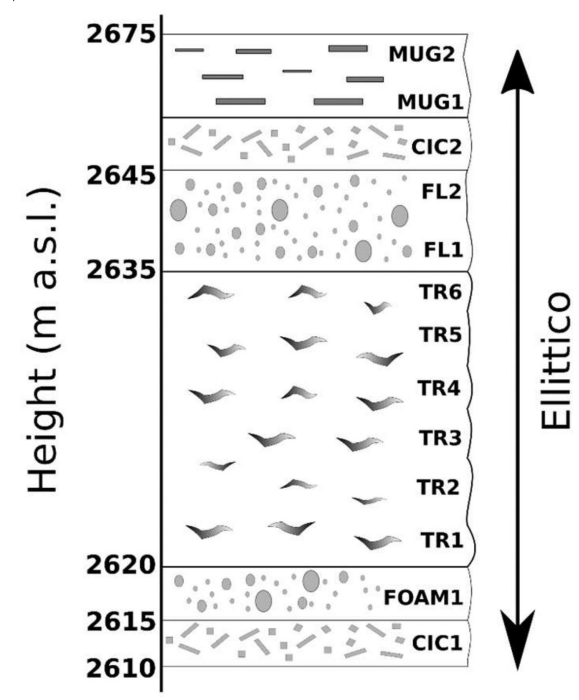

Figure 2. Schematic representation of the sampled sequence. The height (a.s.l.) is reported for each type of volcanic product $(\mathrm{CIC}=$ cicirara lavas, FOAM and FL = highly vesiculated lavas, $\mathrm{TR}=$ banded trachyandesites, MUG = mugearites).

\section{Materials and Methods}

\subsection{Whole-Rock, Mineral Phase Analyses, and Textural Characterizations}

Whole-rock, 2D textural, and mineral phase analyses were performed at the Department of Biological, Geological, and Environmental Sciences of the University of Catania (Italy). The determination of the bulk-rock concentration of major and some trace elements on seven samples was made by X-ray fluorescence (XRF) analysis, using a Philips PW2404 WD-XRF spectrometer standardized according to [28]. The method proposed by [29] was adopted to reduce the matrix effect. Precision is between $1 \%$ and $5 \%$ for major elements 
and between $5 \%$ and $10 \%$ for trace elements. Accuracy was monitored using international standards and was always better than $10 \%$. Water content was determined by gravimetric measurements as a loss on ignition (LOI) and successively corrected for iron oxidation.

Textural investigations on high-contrast back-scattered electron (BSE) images and chemical analyses for crystals were made with a Tescan Vega-LMU scanning electron microscope equipped with an EDAX Neptune XM4-60 microanalyzer energy dispersive system characterized by an ultrathin Be window coupled with an EDAX wavelength dispersive low energy X-ray spectrometer (WDS-LEXS) calibrated for light elements. Operating conditions were set at $20 \mathrm{kV}$ accelerating voltage and ca. $8 \mathrm{nA}$ beam current for obtaining high-resolution BSE images and $20 \mathrm{kV}$ accelerating voltage and $0.2 \mathrm{nA}$ beam current for analyzing major element abundances.

\subsection{Synchrotron X-ray Microtomography (SR $\mu \mathrm{CT}$ ) Measurements}

The characterization of the vesicles and oxides in the samples was performed by high-resolution $\mathrm{SR} \mu \mathrm{CT}$ in phase-contrast mode [30]. Experiments were carried out at the synchrotron radiation for medical physics (SYRMEP) beamline of the Elettra-Sincrotrone Trieste laboratory (Basovizza, Italy).

Samples were prepared to cut the original rocks in parallel-piped blocks with dimensions of about $4 \mathrm{~mm} \times 4 \mathrm{~mm} \times 8 \mathrm{~mm}$. A polychromatic X-ray beam (white beam configuration) delivered by a bending magnet source illuminated the sample in transmission geometry. Filters $(1.5 \mathrm{~mm} \mathrm{Si}+1 \mathrm{~mm} \mathrm{Al})$ were used to suppress the contribution of low energies in the beam spectrum.

For each sample, 1800 projections were recorded with an exposure time/projection of 2 s. The detector was an air-cooled, 16 bit, SCMOS camera (Hamamatsu C11440-22C) with a $2048 \times 2048$-pixel chip. The effective pixel size of the detector set at $1.37 \mu \mathrm{m} \times 1.37 \mu \mathrm{m}$, yielding a maximum field of view of about $2.8 \mathrm{~mm} \times 2.8 \mathrm{~mm}$. The experiments were performed in "local area" [31] and in phase-contrast mode, setting the sample-to-detector distance to $150 \mathrm{~mm}$.

Reconstruction of the 3D tomographic images was performed with the Syrmep Tomo Project (STP) software suite (version 1.4, Elettra-Sincrotrone Trieste, Trieste, Italy) [32]. Pre-reconstruction filters were applied to the datasets for reducing ring artifacts caused by detector inhomogeneity.

\subsection{Three-Dimensional Image Analysis}

3D image processing and analysis of the six imaged trachyandesitic samples was performed using the Pore3D software library custom-developed at Elettra [33]. The 3D visualization (through surface and volume rendering procedures) of reconstructed and processed volumes was performed employing the commercial software VGStudio MAX 2.0 (Volume Graphics, Heidelberg, Germany).

Samples show a characteristic banded appearance given by zones enriched (HB subvolumes) and depleted (LB sub-volumes) in oxides and vesicles (Figure 3). We thus chose to perform analysis on 1) volumes large enough to be representative of the whole samples and including both HB and LB zones and 2) sub-volumes focused on either HB or LB zones containing a high and low amount of vesicles and oxides (Table 1 and Figure 3 ). The extraction of suitable volumes for the analysis (volume of interest (VOI)) of the trachyandesitic samples was performed taking into account the multi-scale heterogeneity of the rocks. Adequate parts of the sample were selected in order to be representative of both the HB and LB volumes. The choice of VOIs for the whole sample analysis was made on a computational-limit basis, by a simple selection of the largest volume analyzable by the hardware. On these volumes, HB and LB sub-volumes were identified and extracted after visual inspection. 


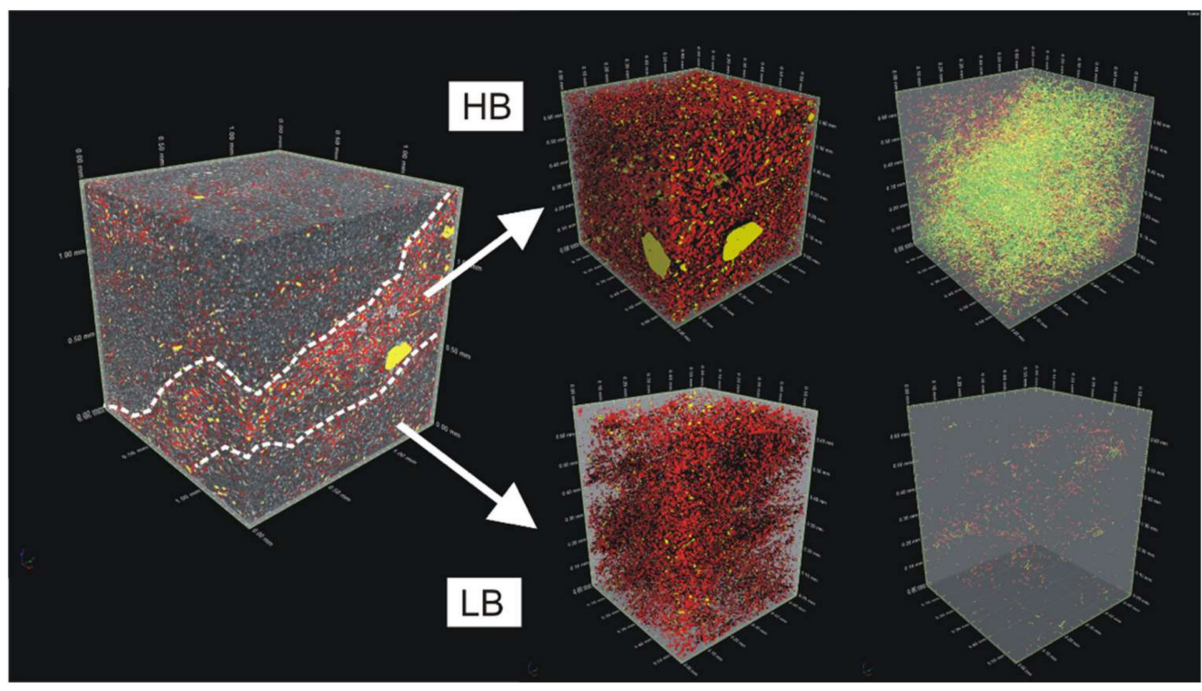

Figure 3. The reconstructed 3D volume of interest $\left(2.57 \mathrm{~mm}^{3}\right)$ of the TR1 sample showing a banded appearance given by HB (high skeleton complexity) and LB (low skeleton complexity) zones. Skeletons evidence different connectivity for the vesicle network in HB compared to LB.

In order to test the representativeness of the extracted VOIs, representative elementary volumes (REVs) tests were performed. For each sample, we considered vesicle and titanomagnetite (timt) volume fraction as the parameter for REV determination and applied the box-counting method [34]. Our results indicate that the extracted VOIs are representative of the whole samples, and their HB and LB sub-portions. VOIs were then extracted and filtered to remove noise and enhance. The next step was the segmentation of the images to obtain binary volumes containing the different classes of the phase of interest. Thresholds were identified by the automatic multi-Otsu method [35] and manually adjusted after visual inspection. For each sample, we extracted two binary datasets corresponding to vesicles and timt, the least dense and densest phases with respect to the trachyandesite assemblage. From sub-volumes, we extracted the bubbles and timt amount and performed morphological analysis (Table 1) in order to calculate the number of objects, their volume, sphericity, and aspect ratio. The connectivity of bubble networks was investigated by a skeletonization approach using the LKC skeletonization algorithm [36]. After skeletonization, an iterative pruning of all branches with sizes $<5$ voxels was applied for removing unnecessary branches and nodes not representing the real connectivity frames.

Table 1. Results of 3D image analysis.

\begin{tabular}{|c|c|c|c|c|c|c|c|c|}
\hline Sample & $\begin{array}{c}\text { Analyzed } \\
\text { Portion }\end{array}$ & $\begin{array}{c}\text { VOI } \\
\left(\mathrm{mm}^{3}\right)\end{array}$ & $\begin{array}{l}\text { Amount } \\
\text { (vol.\%) }\end{array}$ & $\begin{array}{c}\text { Number Density } \\
\quad\left(\# / \mathrm{mm}^{3}\right)\end{array}$ & $\begin{array}{l}\text { Volume } \\
\left(\mathrm{mm}^{3}\right)\end{array}$ & Sphericity $^{1}$ & Aspect Ratio ${ }^{1}$ & $\begin{array}{c}\text { Connectivity } \\
\text { Density } \\
\left(\mathrm{mm}^{-3}\right)\end{array}$ \\
\hline \multicolumn{9}{|c|}{ Bubbles } \\
\hline TR1 & WHOLE & 2.57 & 6.26 & - & - & - & - & - \\
\hline \multirow{3}{*}{$\begin{array}{l}\text { TR1 } \\
\text { TR2 }\end{array}$} & HB & 0.32 & 11.15 & 148,547 & $7.50 \times 10^{-7}$ & 0.89 & 0.06 & 9763 \\
\hline & LB & 0.21 & 2.02 & 176,293 & $1.15 \times 10^{-7}$ & 0.94 & 0.05 & 5 \\
\hline & WHOLE & 2.57 & 6.37 & - & - & - & - & - \\
\hline \multirow{3}{*}{$\begin{array}{l}\text { TR2 } \\
\text { TR3 }\end{array}$} & HB & 0.21 & 11.39 & 88,771 & $1.28 \times 10^{-6}$ & 0.83 & 0.10 & 7399 \\
\hline & LB & 0.21 & 2.28 & 90,891 & $2.50 \times 10^{-7}$ & 0.90 & 0.07 & 292 \\
\hline & WHOLE & 2.57 & 8.95 & - & - & - & - & - \\
\hline \multirow{3}{*}{$\begin{array}{l}\text { TR3 } \\
\text { TR4 }\end{array}$} & HB & 0.07 & 13.85 & 120,240 & $1.15 \times 10^{-6}$ & 0.85 & 0.08 & 15,131 \\
\hline & LB & 0.07 & 2.77 & 159,507 & $1.75 \times 10^{-7}$ & 0.91 & 0.06 & 101 \\
\hline & WHOLE & 2.57 & 7.47 & - & - & - & - & - \\
\hline \multirow{3}{*}{$\begin{array}{l}\text { TR4 } \\
\text { TR5 }\end{array}$} & $\mathrm{HB}$ & 0.16 & 18.12 & 81,560 & $2.22 \times 10^{-6}$ & 0.88 & 0.08 & 35,524 \\
\hline & LB & 0.16 & 2.38 & 15,2516 & $1.57 \times 10^{-7}$ & 0.97 & 0.04 & 30 \\
\hline & WHOLE & 2.57 & 7.30 & - & - & - & - & - \\
\hline \multirow{3}{*}{$\begin{array}{l}\text { TR5 } \\
\text { TR6 }\end{array}$} & HB & 0.32 & 12.89 & 156,027 & $8.25 \times 10^{-7}$ & 0.93 & 0.03 & 43,933 \\
\hline & LB & 0.32 & 4.00 & 229,538 & $1.74 \times 10^{-7}$ & 0.92 & 0.04 & 460 \\
\hline & WHOLE & 2.57 & 6.85 & - & - & - & - & - \\
\hline
\end{tabular}


Table 1. Cont.

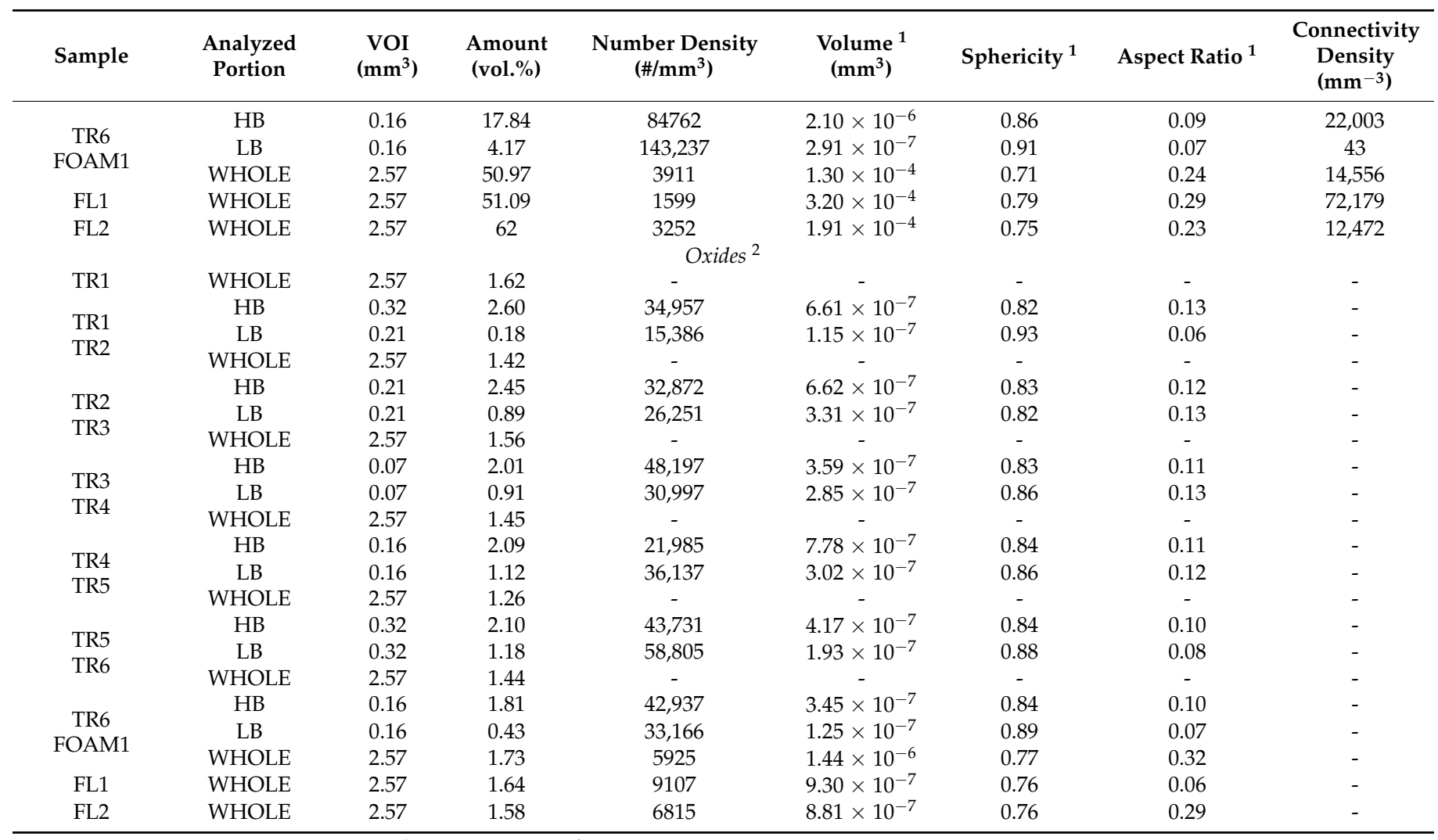

${ }^{1}$ Average values. ${ }^{2}$ Amount (vol.\%) normalized to the solid phase.

\section{Results}

\subsection{Whole-Rock Geochemistry, Texture, and Mineral Composition}

The sampled flows have a mildly to significantly evolved composition, ranging from trachybasaltic to trachyandesitic (Table 2 and Figure 4). Results of the whole-rock analysis are reported in Table 2; SEM mineral chemistry is reported in Table S1. From the base, the sequence starts with the eruption of CIC1 trachybasaltic lava $\left(\mathrm{SiO}_{2}=49.7\right.$ wt. $\left.\%, \mathrm{Mg \#}=33\right)$, which shows the typical presence of large (centimeter-scale) crystals of plagioclase, with the subordinate and smaller individual of clinopyroxene and olivine. A detailed description of this rock texture and mineral compositions is given in [27]. This lava is overlaid by the FOAM1 flow, characterized by its high vesiculated appearance because of the large presence of bubbles ( $51 \mathrm{vol} . \%$ ) of size up to $1 \mathrm{~mm}$, and that is characterized by rough walls, often corresponding to the shape of any adjacent microcrystals (Figure 5). This lava has a trachyandesitic composition $\left(\mathrm{SiO}_{2}=60.3 \mathrm{wt} . \%, \mathrm{Mg \#}=24\right)$ and aphyric texture, given by abundant microlites $(<100 \mu \mathrm{m})$ of K-feldspar (Figure 6$)$, subordinate individuals of clinopyroxene and oxide with size distribution $<10 \mu \mathrm{m}$.

At the top of the vesiculated lava, a sequence of six lava flows (TR1-TR6) showing banded appearance at the macroscale crop out. Chemical analyses of samples TR3, TR4, and TR6 indicate a trachyandesitic composition $\left(\mathrm{SiO}_{2}=58.97-59.45\right.$ wt.\%, Mg\# = 24.4-25; Table 2 and Figure 4). BSE images of the TR1 sample (Figure 5) show that the rock texture is mainly given by tiny microcrystals of K-feldspar (Figure 6) with size $<100 \mu \mathrm{m}$ and subordinate pyroxenes and oxides. Few clusters of microphenocrysts (size up to $300 \mu \mathrm{m}$ ), given by the association of individual plagioclase, K-feldspar, oxides, amphibole, pyroxene, and rare anhydrite occur dispersed in the microcrystalline matrix. These clusters are always associated with abundant vesicles with respect to the rest of the investigated areas (see Section 4.2). The trachyandesitic lavas are covered by two highly vesiculated lavas (FL1 and FL2) with basaltic trachyandesite composition $\left(\mathrm{SiO}_{2}=51.17-53.2, \mathrm{Mg} \#=26-30\right)$. They are characterized by the abundant presence of bubbles (FL1 = 51 vol.\%; FL2 = 62 vol.\%) 
with size up to $600 \mu \mathrm{m}$, display aphyric texture (Figure 5), constituted by microcrystals (few tens of $\mu \mathrm{m}$ in size) of K-feldspar and plagioclase (Figure 6). The sequence is topped by two mugearitic lava flows, described in [26].

Table 2. Results of whole-rock analysis for major oxides (wt.\%) and trace elements (ppm).

\begin{tabular}{|c|c|c|c|c|c|c|c|c|}
\hline Sample & CIC1 & CIC2 & FOAM1 & FL1 & FL2 & TR3 & TR4 & TR6 \\
\hline \multicolumn{9}{|c|}{ Major oxides ${ }^{1}$} \\
\hline $\mathrm{SiO}_{2}$ & 49.70 & 50.03 & 60.32 & 53.52 & 51.17 & 58.97 & 59.45 & 59.13 \\
\hline $\mathrm{TiO}_{2}$ & 1.46 & 1.47 & 1.69 & 1.85 & 2.01 & 1.27 & 1.21 & 1.29 \\
\hline $\mathrm{Al}_{2} \mathrm{O}_{3}$ & 20.91 & 20.85 & 16.13 & 17.72 & 17.27 & 19.06 & 19.16 & 18.97 \\
\hline $\mathrm{Fe}_{2} \mathrm{O}_{3}$ & 8.20 & 8.24 & 8.38 & 9.38 & 10.81 & 6.04 & 5.70 & 6.00 \\
\hline $\mathrm{MnO}$ & 0.16 & 0.17 & 0.14 & 0.20 & 0.21 & 0.17 & 0.16 & 0.17 \\
\hline $\mathrm{MgO}$ & 1.80 & 1.63 & 1.15 & 1.81 & 1.71 & 0.89 & 0.82 & 0.89 \\
\hline $\mathrm{CaO}$ & 11.00 & 10.39 & 3.84 & 7.15 & 8.41 & 3.89 & 3.73 & 3.92 \\
\hline $\mathrm{Na}_{2} \mathrm{O}$ & 3.79 & 3.92 & 4.96 & 4.45 & 4.12 & 5.46 & 5.44 & 5.41 \\
\hline $\mathrm{K}_{2} \mathrm{O}$ & 2.24 & 2.46 & 2.89 & 3.22 & 3.19 & 3.88 & 3.97 & 3.85 \\
\hline $\mathrm{P}_{2} \mathrm{O}_{5}$ & 0.74 & 0.84 & 0.51 & 0.71 & 1.11 & 0.37 & 0.36 & 0.38 \\
\hline L.O.I. & 1.09 & 1.22 & 1,41 & 0.82 & 0.9 & 0.17 & 0.17 & 0.1 \\
\hline \multicolumn{9}{|c|}{ Trace elements } \\
\hline $\mathrm{Sr}$ & 1660 & 1544 & 894 & 1240 & 1049 & 795 & 770 & 797 \\
\hline $\mathrm{V}$ & 174 & 180 & 82 & 150 & 226 & 52 & 48 & 53 \\
\hline $\mathrm{Cr}$ & 6 & na & 4 & na & na & 2 & 2 & na \\
\hline Co & 19 & 18 & 13 & 11 & 23 & 4 & 4 & 4 \\
\hline $\mathrm{Ni}$ & 13 & 12 & 35 & 7 & 9 & 6 & 8 & 8 \\
\hline $\mathrm{Zn}$ & 86 & 88 & 83 & 92 & 116 & 92 & 90 & 90 \\
\hline $\mathrm{Rb}$ & 31 & 34 & 72 & 53 & 61 & 73 & 74 & 69 \\
\hline $\mathrm{Y}$ & 30 & 32 & 28 & 37 & 45 & 42 & 43 & 40 \\
\hline $\mathrm{Zr}$ & 327 & 336 & 443 & 438 & 448 & 538 & 547 & 528 \\
\hline $\mathrm{Nb}$ & 64 & 67 & 103 & 94 & 108 & 122 & 122 & 118 \\
\hline $\mathrm{Ba}$ & 1112 & 1225 & 1271 & 1518 & 1443 & 1620 & 1665 & 1639 \\
\hline $\mathrm{La}$ & 119 & 123 & 137 & 144 & 173 & 154 & 153 & 160 \\
\hline $\mathrm{Ce}$ & 188 & 203 & 219 & 232 & 286 & 258 & 276 & 259 \\
\hline $\mathrm{Pb}$ & 12 & 12 & 9 & 6 & 9 & 8 & 17 & 13 \\
\hline Th & 10 & 13 & 20 & 20 & 23 & 24 & 25 & 25 \\
\hline
\end{tabular}

\footnotetext{
${ }^{1}$ Major oxides are normalized to anhydrous composition; na: below detection limit.
}

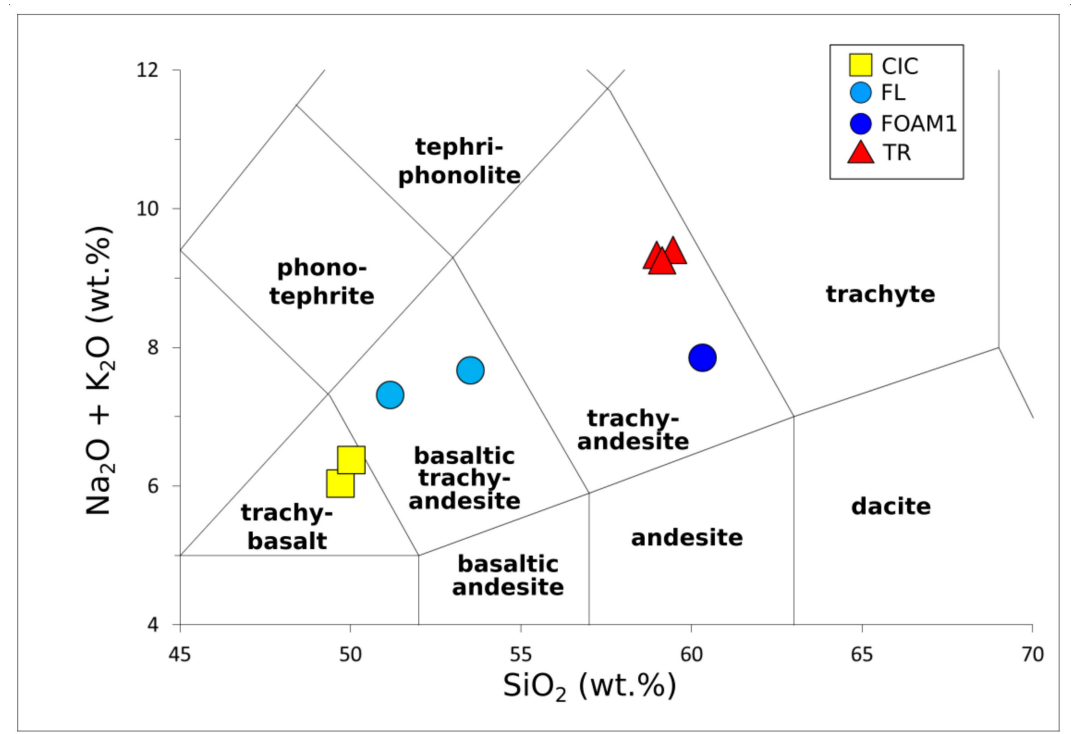

Figure 4. Total alkali vs. silica diagram showing the composition of selected samples from the investigated section. 


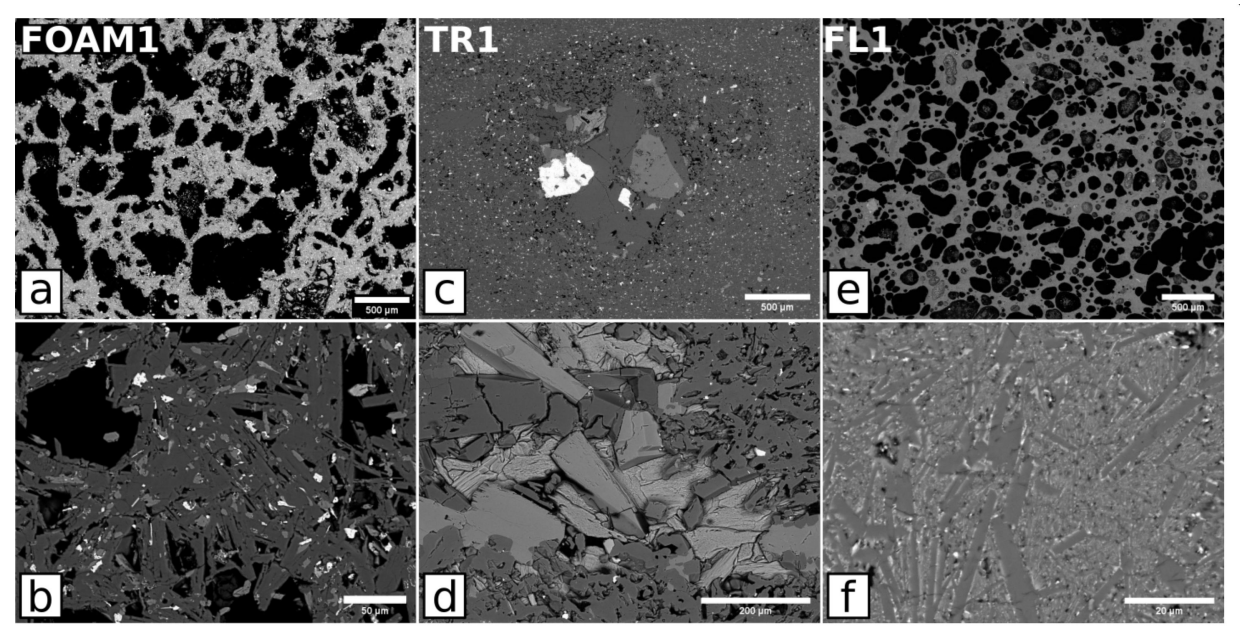

Figure 5. Backscattered electron images of FOAM1, TR1, and FL1 aphyric lavas at low (a,c,e) and high $(\mathbf{b}, \mathbf{d}, \mathbf{f})$ magnification. FOAM1 $(\mathbf{a}, \mathbf{b})$ displays high vesicularity with bubbles having irregular walls shaped by microlites of the groundmass. Images of TR1 (c,d) show at microscale the nature of the banding given by HB and LB areas, i.e., the former given by microlites of feldspar, and the latter characterized by the association of microlites, microphenocrysts (feldspar, pyroxenes, oxide, and anhydrite), and vesicles. The FL1 lava (e,f) displays abundant vesicularity with spherical and sub-spherical bubbles in a fine groundmass showing also the presence of glass.

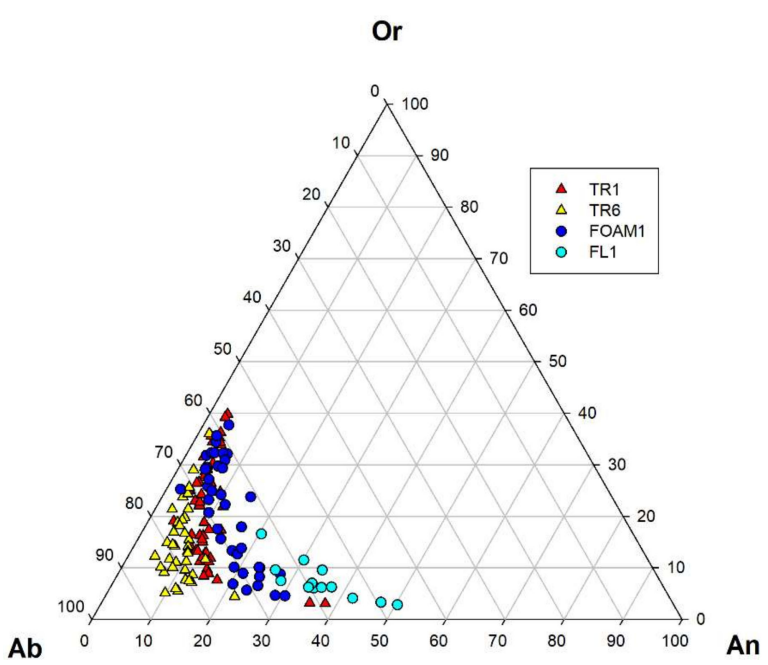

Figure 6. Ternary classification diagram showing the composition of feldspar in trachyandesites and highly vesiculated lavas.

\subsection{Three-Dimensional (3D) bubbles and Oxides Distribution}

At the macroscale, the most evolved products of the sequence (TR1-TR6) show a banded appearance due to the presence of oxide-rich micro-portions associated with abundant vesiculation. A detailed study of the bubble-oxide associations was carried out, investigating the microtomographic images of the trachyandesitic samples (Figure 3). Indeed, the TR1-TR6 sample suite shows general bubble contents ranging between 6.26 and 8.95 vol.\%, whereas HB sub-volume vesicularity varies between 11.15 and 18.12 vol.\% (Table 1); LB sub-samples are depleted in bubbles, with content ranging between 2.02 and 4.17 vol.\%. The same pattern is shown by the amount of oxides: whole samples contain 1.17 to 1.52 vol.\% of timt, HB portions are enriched up to $2.31 \mathrm{vol} \%$, whereas LB portions contents range between 0.18 and 1.14 vol.\%. Results of basic analysis also indicate a different degree of connection of the bubbles in HB and LB portions: higher values of the Euler characteristic (E) for the LB portions with respect to the HB indicate that 
bubbles in the first are mainly isolated, whereas they can form an extended network in the latter. These results are confirmed by the connectivity density values (CD) retrieved by the skeleton analysis. The higher is CD, the more connected is the analyzed volume. For each sample, the $\mathrm{HB}$ portions show $\mathrm{CD}$ values of one to two orders of magnitude higher than LB (see Table 1). This pattern is clearly evidenced by skeletons in Figure 3, showing a high complexity for HB sub-volume, with respect to the LB sub-volume of the TR1 sample.

HB portions contain fewer but larger bubbles per unit volume (\#/vol), compared to LB. The vesicle size distribution (VSD), shown as the volume fraction of bubbles in a defined size range (Figure 7, see [37]), displays for LBs two peaks corresponding to the class of bubbles with a size range of $10^{2}$ and $10^{3} \mu \mathrm{m}^{3}$, whereas HBs show peaks centered at $10^{3}$ and $10^{6} \mu^{3}$. Finally, morphological analyses indicate that bubbles in HB portions are more deformed than the LB ones, as testified by the higher values of sphericity and lower aspect ratios of bubbles in LB with respect to HB (see Table 1).

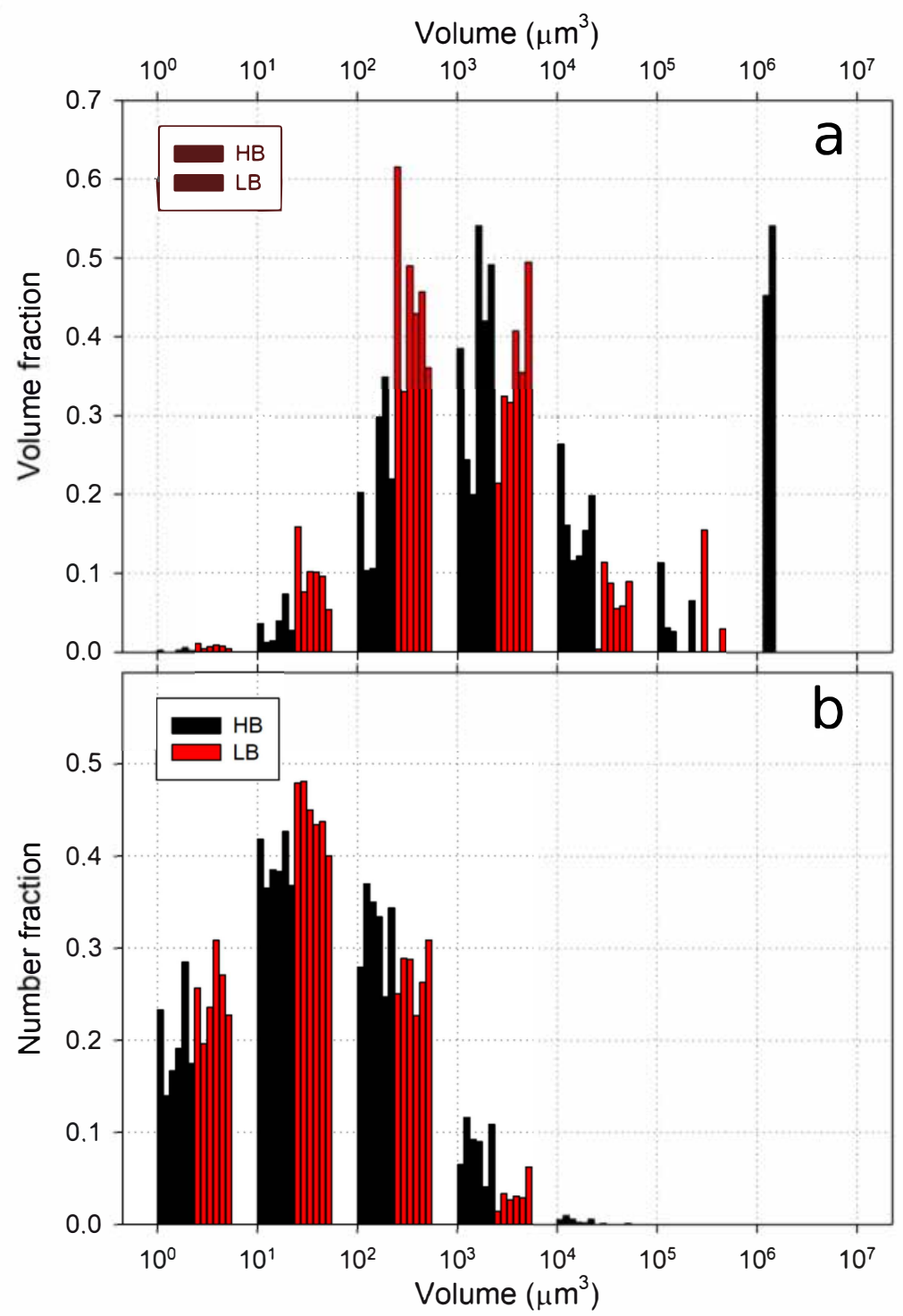

Figure 7. Vesicle size distribution calculated as volume fraction (a) and number fraction (b) showing the differences between HB and LB portion of the TR samples. For each class, samples represented as a single bar are arranged left to right from TR1 to TR6. The top diagram displays that LB samples have peaks at the lower size $\left(10^{2}-10^{3} \mu \mathrm{m}^{3}\right)$ with respect to $\mathrm{HB}$ samples peaked at $10^{3}$ and $10^{6} \mu \mathrm{m}^{3}$. The lower diagram does not show any difference in the overall distribution of bubbles number fraction between HB and LB portions. 
The distribution of oxides mirrors that of the bubble, being timt minerals more abundant in HB portions (from 1.49 to 2.31 vol.\%) than LB (0.18-1.14 vol.\%). Although their number density does not show a marked correlation with one of the two kinds of subsample portions (see Table 1), these minerals are clearly larger in HB volumes than in LB (Figure 3).

\section{Discussion}

\subsection{Origin of Trachyandesitic Magmas at Mount Etna}

The title of this paragraph is one of the most intriguing issues in the comprehension of the evolution of Mount Etna. According to the classic paradigm, in a volcanic succession, the origin of high silica rocks should be strictly correlated to a differentiation process, mainly occurring through progressive fractional crystallization processes of an initial basaltic melt. However, the episodic emission of the trachyandesites poses some problems to accept such a model as univocal. In fact, these silica-rich lavas are intercalated within a compositionally uniform basaltic succession and the sequence shows only two thin intermediate terms (FL1-2) outcropping at the top of the trachyandesitic products. This association is not adequately explainable by the process of differentiation. It has long been accepted that Etnean magmas differentiate at depth through fractionation of mafic phases such as olivine, clinopyroxene, and titanomagnetite [8,13-19]. This differentiation is able to produce the Etnean hawaiites, constituting most of the Ellittico and Recent Mongibello sequences from primitive alkali basalts [38-40]. In order to produce more evolved, silica-rich terms, a magma batch should pond at intermediate-low pressure levels long enough to promote the onset of a series of chemical/physical processes (crystal nucleation, growth, settling, separation, magma mixing, host-rock assimilation, etc.), which ultimately lead to the production of differentiated melts. In addition, the differentiation due to crystal fractionation would constantly act for a certain time, continuously producing terms with an intermediate degree of evolution. However, only small volumes of these lavas, represented by the upper foamy layers, have been erupted. In fact, the trachyandesites are embedded within the "cicirara" and mugearitic lavas all displaying a similar basaltic composition [27], thus constituting a critical point for asserting the existence of low-pressure magma chambers-why there should exist only one layer of differentiated lavas, and why is there a lack of lavas with intermediate compositions either above or below these products?

Moreover, after reviewing literature data on the Recent Mongibello and Ellittico sequences, it was found [7] that the Mg content of erupted products tends to increase with time (a time span of ca $60 \mathrm{ka}$ ), pointing toward more primitive compositions. The ultimate endmembers of this process are represented by the Mg-rich, sub-aphyric, alkali basalts emitted during the eruptions of Mount Spagnolo and Mount Maletto [17-19]. A shift toward Mg-rich magmas has also been observed in recently erupted lavas [1,2,9], especially in the post-1971 activity. Therefore, the differentiation process of the Etnean magmas is ambiguous, and the input of deep, volatiles-rich melts has represented a repeated and peculiar factor in the Etnean evolution. Within such a complex scenario linking the genesis of trachyandesitic magma only to a straightforward process of crystal, fractionation seems questionable, especially considering the uniqueness of these lavas within the Ellittico sequence. With the aim to simulate the genesis of the trachyandesites, two alternative processes have been explored.

\subsubsection{Model 1: "Classical" Differentiation via Fractional Crystallization}

The first model was built to account for the production of Mount Etna trachyandesites via progressive fractional crystallization (FC) of the least evolved product exposed in the studied sequences, i.e., the trachybasaltic sample CIC1. To encompass the variability of the products exposed along the studied sequence, a double-step FC model was performed by considering the mildly evolved basaltic trachyandesite FL1 as an intermediate product [41]. In a first instance, Rayleigh distillation equations [42] were adopted to roughly estimate the 
extent of fractional crystallization for each step, assuming $\mathrm{Zr}$ as a perfectly incompatible element (e.g., mineral-melt distribution coefficient equal to zero; see also [37,41,43]. Afterward, mass balance calculations based on major elements (oxide wt.\%) have been used to simulate the two FC steps (step 1 = from CIC1 to FL1; step 2 = from FL1 to TR3). In each step of the model, the composition of the natural arrival melts was matched by a hypothetical (calculated) melt composition obtained by the subtraction of solid assemblages made of real mineral phases reported from Mount Etna lavas and/or gabbroic xenoliths [39,44] (see Table S2). The accuracy of each FC step was evaluated by means of the least square method, following the equation

$$
S=\sum_{i=1}^{n} r_{i}^{2}
$$

where the optimal parameter $S$ was fitted by minimizing the sum of squared residuals $r^{2}$ between the predicted values for each oxide " $i$ " (e.g., $\mathrm{SiO}_{2}$ wt.\% of the natural sample) and the values calculated from the melting model (e.g., $\mathrm{SiO}_{2} \mathrm{wt} . \%$ of the calculated melt) (Table S2). For our purposes, the model was considered accurate when $S<1$, i.e., when the difference between modeled and calculated parameters, expressed as oxides wt.\%, was well within the analytical errors (i.e., XRF and/or Electron Probe Microanalyzer determinations) [45].

The trace element distribution in the calculated melts was obtained using specific partition coefficients (Kd, Table S3), following the formulation of [42] for Rayleigh fractionation

$$
\mathrm{C}_{\mathrm{L}}=C_{0} \times F^{(D-1)},
$$

where $C_{0}$ is the amount of the chosen element in the starting (natural) magma, $C_{\mathrm{L}}$ is the amount of trace element calculated in the resultant magma, $F$ is the residual melt percentage, and $D$ the partition coefficients weighted for the percentage of fractionated minerals obtained by the mass balance calculation.

Results showed that the mildly evolved basaltic trachyandesite FL1 was produced after 39\% fractional crystallization of a gabbroic solid assemblage composed of olivine $(2.6 \%)$, clinopyroxene $(6.0 \%)$, plagioclase $(81.7 \%)$, Ti-magnetite $(6.0 \%)$, and apatite $(3.8 \%)$. The second FC step, from FL1 to TR3, was simulated by $26 \%$ removal of a gabbroic solid assemblage composed of amphibole (4.0\%), clinopyroxene (23.1\%), plagioclase $(42.0 \%)$, apatite $(6.8 \%)$, Ti-magnetite $(16.8 \%)$, and biotite $(7.3 \%)$. The accuracy of both steps was ascertained by the low $\mathrm{S}$ parameters ( 0.37 and 0.45 , respectively), and by the good match between the calculated and real trace element compositions (Table S2). In this framework, an overall fractionation degree of about $55 \%$ could account for the production of the most evolved trachyandesites from a starting trachybasaltic melt. In addition to its mathematical accuracy, the solidity of the proposed FC model relies on the modal/compositional match between the removed solid assemblages and the real gabbroic xenoliths reported by [44] from the Mount Etna 2001 and 2002-2003 eruptions. These xenoliths, in fact, are thought to belong to the high-velocity body (HVB) imaged beneath Mount Etna by seismic tomography [46,47]. According to several authors [44,48,49], the HVB represents an intrusive gabbroic body located between 3 and $13 \mathrm{~km}$ b.s.l., generated during the onset of efficient crystal-melt separation processes in the plumbing system of Mount Etna. Moreover, the HVB is intimately linked to the massive differentiation processes that took place during the Ellittico volcanic phase, representing thus the remnant of ancient magma ponding zones or crystal mushes, whose onset was favored during this specific stage of Mount Etna evolution. The results of this model could represent the "counterpart" of this theory and show that the genesis of trachyandesites at Mount Etna is a direct consequence of the fractional crystallization of amphibole-phlogopite-bearing gabbroic assemblages.

On the other hand, it should be underlined that the estimated FC process required to produce trachyandesites from trachybasaltic melts after $55 \%$ removal of gabbroic assemblages simulates only the last part of the liquid line of descent of Mount Etna magma. Indeed, samples similar to CIC1 are generally produced by $12-15 \%$ FC of a more primitive trachybasaltic melt [8], which in turn is the result of $9-12 \%$ FC of a primitive basalt in 
equilibrium with the mantle source [50]. Overall, this means that at least $65-70 \%$ FC of a primitive, mantle-derived Etnean melt is required to generate the most evolved products of the Ellittico volcanic stage.

\subsubsection{Model 2: The Production of Evolved Melts by Partial Melting of the Host Rocks}

An alternative genetic hypothesis for Mount Etna trachyandesites could be drawn starting from the consideration that the present-day volcanic edifice emits huge quantities of gasses not budgeted within the classical view of magma, but by the basaltic melt actually erupted. This gas budget can be estimated to be up to 10 times the maximum $\mathrm{H}_{2} \mathrm{O}$ that could be dissolved in magma and $40 \%$ more moles of gas $\left(\mathrm{H}_{2} \mathrm{O}, \mathrm{CO}_{2}\right.$, and $\left.\mathrm{S}\right)$ than moles of basalt [51]. Although we do not have any direct measure of gas emissions during the ancient Mount Etna evolutionary stages, the frequent occurrence of pyroclasts embedded within the Ellittico sequence makes it plausible to hypothesize that the volatiles involvement during the Ellittico stage was even higher than in present-day activity. Gasses are hot, and the effect of their passage within the plumbing system has been investigated theoretically by [51], who found that one mole of gas at an initial temperature of $1200{ }^{\circ} \mathrm{C}$ can supply a $\Delta \varepsilon$ of $18,412.5 \mathrm{~J}$ to the surrounding rocks. Such volatiles could have provided enough heat to maintain the surrounding rocks hot enough to overcome their solidus temperature, as testified also by field observation at Mount Etna, where non-eruptive fractures remain incandescent for months as a result of gas flux (Figure 8).

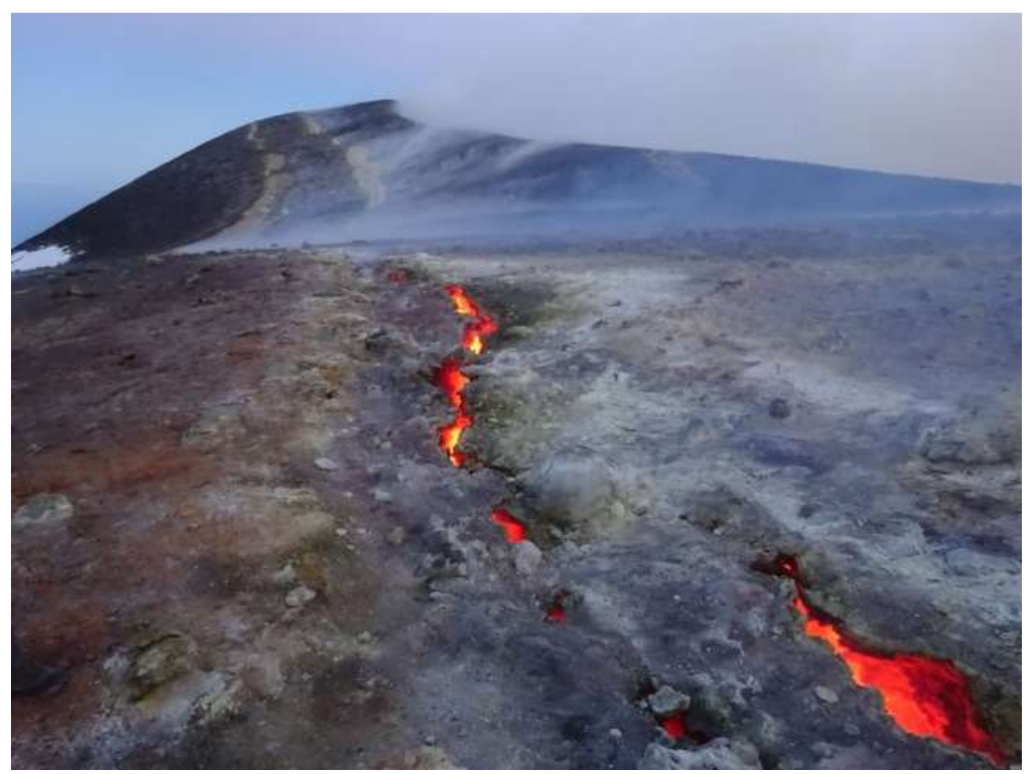

Figure 8. Incandescence of gas fluxed fractures (tens centimeters to meters wide) at Mount Etna summit craters (December 2016).

This gas-induced heating process could be even more efficient if the surrounding rocks are multi-phase aggregates with a low melting point. Geophysical investigations have demonstrated the presence of subvolcanic bodies beneath the Etnean edifice [46,47], which have been interpreted as gabbroic rocks solidified in intratelluric conditions due to the innumerable dyke intrusions that accompanied the development and evolution of the Etnean volcano.

Starting from this consideration, we hypothesize that Ellittico trachyandesites could have been directly segregated by gas-induced partial melting [52] of the igneous rocks with cicirara-like composition $[27,53]$ crystallized within the plumbing system. This process would also be able to enrich the newly formed melt in elements transported along with the hot gaseous phase (e.g., K; see [7]).

Similar to what was proposed above, numerical simulations through mass balance calculations were conducted to simulate the partial melting of a megacryst-rich mugearitic 
lava similar to those that erupted at Mount Etna shortly before the trachyandesitic/trachytic products. The partial melting conditions of the "source" rocks were simulated by using the eutectic composition of the systems as a function of the degree of partial melting. A "melting + recrystallization" mass balance model enabled us to simulate the contribution of the fusible components from each mineral phase of the source rocks and then reproduce the major element composition of the produced trachyandesitic/trachytic magmas. The partial melting degree $(F)$ associated with the production of trachyandesitic/trachytic melts was then calculated as the difference between the melted fertile assemblage and the recrystallized restitic residuum. Once fixed the mineral phase eutectic proportions, nonmodal batch melting equations [42] were adopted to model the trace element distribution of the produced melt, following the methods described by $[44,50]$.

Results show that high partial melting $(\sim 21 \%$ calculated from major elements; up to $42 \%$ calculated on trace elements) of the host mugearitic rocks are able to produce a melt similar in composition to the real trachyandesitic/trachytic products of the Ellittico stage (Table S2). During this melting process, the eutectic contribution of mineral phases is positively dominated by andesine plagioclase (microlites population, see [27], followed by labradorite-bytownite plagioclase (phenocrysts population), low Mg\# clinopyroxene (microlites population), olivine, and interstitial glass (Tables S4 and S5). This positive contribution is counterbalanced by the recrystallization (i.e., negative melting proportion) of high Mg\# clinopyroxene (phenocryst population) and Ti-magnetite. The only discrepancy between real trachyandesitic/trachytic rocks and calculated melts that is given by $\mathrm{K}_{2} \mathrm{O}$ was resolved by assuming that significant amounts of $\mathrm{K}$ are transported by the gaseous phase, which triggered the melting process, in accordance with [7].

The volume of rocks involved in the partial melting (Wv) was calculated considering the following equation [51]:

$$
\mathrm{Wv}=\frac{\Delta \varepsilon}{\rho \cdot[L+c \cdot(T l-T m)])}
$$

where:

- $\Delta \varepsilon=18,412.5 \mathrm{~J} \cdot \mathrm{s}^{-1}$ is the energy flux carried by gases migrating through the plumbing system [51];

- $c=1.4 \times 10^{3} \mathrm{~J} \cdot \mathrm{kg}^{-1} \cdot \mathrm{K}^{-1}$ is the specific heat of an Etnean basalt [51];

- $\mathrm{Tm}=100^{\circ} \mathrm{C}$ is the $\mathrm{T}$ at $3 \mathrm{~km}$ of depth considering the average geothermal gradient;

- $\mathrm{Tl}=1100{ }^{\circ} \mathrm{C}$ is the conservative liquid temperature of trachyandesites calculated using MELTS;

- $\rho=2800 \mathrm{~kg} / \mathrm{m}^{3}$ is the rock density;

- $L=5.0 \times 105 \mathrm{~J} \cdot \mathrm{kg}^{-1}$ is the latent heat for Etnean basaltic lavas $[18,54,55]$.

Results indicate that the above-considered gas flux would be able to raise the temperature of $0.13 \mathrm{~m}^{3} / \mathrm{s}$ of basaltic rocks to $1100{ }^{\circ} \mathrm{C}$. A conservative estimation of $0.046 \mathrm{~km}^{3}$ for the trachyandesitic lavas volume was performed, taking into account their thickness $(15 \mathrm{~m})$ and supposing that a single eruptive event covered an area of $3 \mathrm{~km}^{2}$ calculated on the basis of their distance from the main crater $(2800 \mathrm{~m})$. In order to produce such an amount of magma by $\sim 21-42 \%$ of partial melting, a total volume of $0.11-0.23 \mathrm{~km}^{3}$ of parent basaltic rock should be involved in heating and melting. According to the estimated heating rate of $0.13 \mathrm{~m}^{3} / \mathrm{s}$, the erupted of trachyandesites could have been produced in 25-50 years.

It is interesting to notice how the results of the gas-induced melting process modeled in our study on the basis of numerical and thermodynamic simulations are extremely similar to what was previously reproduced by High Temperature experiments on natural crystal-rich mugearites aimed at modeling the flow rheology of Etnean lavas [53]. In their model, the authors of [53] show that crystal-rich mugearites are capable of initial melting at $\mathrm{T}$ between 1000 and $1075^{\circ} \mathrm{C}$, generating a glass phase rich in $\mathrm{Si}, \mathrm{Al}$, and alkalis due to the significant contribution of plagioclase during melting. This product (glass) is extremely comparable to the trachyandesites reported in our study (Table 1 and Table S3). Although 
a precise quantification of the amount of partial melting obtained by HT experiments is not directly mentioned in the model presented in [53], it can be speculated that the reported decrease in crystal fraction, from $70 \%$ down to $30 \%$, with increasing $T$ is consistent with the partial melting degrees (21-42\%) simulated in our model. Furthermore, the progressive decrease of plagioclase, pyroxene, and olivine and the parallel increase of Ti-magnetite crystal fractions reported by the same authors resembles the eutectic contribution calculated in this study (Table S2).

\subsection{Magmatic Process and Eruptive Dynamics: Clues from uCT Results}

The foamy-to-banded characters of the trachyandesites can be used as a tool to interpret the eruptive dynamics and crystallization process. The FOAM1 sample at the bottom of the sequence can be considered the highest part of a compositionally homogeneous magma-feeding column. The high vesicle content indicates that this gas-rich melt rose and erupted in a very short time, developing high vesicularity and crystallizing K-rich feldspar contemporaneously to the bubble expansion, as testified by the rough walls of vesicles (Figure 5). The banded lavas, constituting the larger volume of the silica-rich sequence, followed the emission of these products. The banded appearance at the macroscopic scale originates from the presence of dark and light layers made by high (HB) and low (LB) amounts of oxides and bubbles. The higher values of connectivity density of the bubble networks in $\mathrm{HB}$ portions coincide with higher average bubbles volume and with the presence of two main peaks at the $10^{3}$ and $10^{6} \mu \mathrm{m}^{3}$ classes of the bubble size distributions (Figure 7). Chemical analysis on minerals in HB and LB portions do not show remarkable differences, indicating a compositional homogeneity. The association of high vesicularity and high amount of timt remarks the affinity between bubbles and oxides already investigated by [56], who suggest, for andesitic melts, in situ crystallization of oxides on the melt side of the bubble-melt interface. Similar features are observed in the trachyandesitic samples investigated in the present study.

The textural differences in the vesicle analysis in HB and LB must be linked to differing pressure conditions established within the conduits shortly before eruption. In particular, the melt constituting HB bands underwent more pronounced bubble nucleation and growth, probably related to a shallower depth with respect to the LB melt portions. This, in turn, promoted also rapid crystallization (and transport) of Ti-Fe oxides. On the contrary, the LB portions represent magma located in a deeper part of the plumbing system, where degassing was less prominent and bubbles were not efficiently able to grow, coalesce, move, and promote oxide nucleation and transport.

Finally, the association of $\mathrm{HB}$ and LB at millimetric scale in TR lavas could be attributed to mingling processes of the two magma portions started in the very shallow part of the conduit during the ascent, immediately prior to eruption. The recent advances in the comprehension of magma transport can explain the efficiency of the mingling process during its rise through dyke systems. In particular, it has been demonstrated that magma migration within dykes can occur in transitional to turbulent regimes [57], and efficient way to trigger mingling and explain the banded appearance observed in the Etnean trachyandesites. The high ascent rate required for an efficient instauration of a turbulent regime could have been boosted by a large amount of gas in the system, testified by the high vesicularity in the FOAM1 and FL lavas.

The highly vesiculated lavas topping the TR sequence show intermediate chemical and mineralogical characters between the basaltic and the silica-rich members of the sequence. These basaltic lavas display feldspar with the anorthoclase-to-andesine composition (Figure 6), suggesting mixing between the residual TR melt in the lowest part of the feeding dykes and new "fresh" mafic magma entering the system, which later was emitted as the CIC2 lava flow. Mineralogy of these samples indicates that at the time of mixing, the two endmembers were at least at $\mathrm{T}$ of liquidus since microlites with a similar composition to TR or CIC samples are absent. A further hint of the mixing process is provided by the bubble morphology, which shows smooth walls and high sphericity, an indication of 
low viscosity and high $\mathrm{T}$ of the melt during the gas exsolution. All these characters thus indicate that inputs of basaltic magma, probably accompanied by high gas flux, drained the residual evolved magmas in the feeding system, restoring the basic character of the Ellittico volcanic center.

\section{Conclusions}

The multidisciplinary study of the uppermost sequence of the Ellittico volcanic phase, characterized by the rare outcrop of banded trachyandesitic lavas interbedded within basaltic products, allowed us to investigate both the genetic process and eruptive dynamics of some of the most evolved products erupted by Mount Etna.

Coupling chemical, textural, mineral, and 3D investigations with mass balances calculations allowed us to model the genetic process for the evolved products of Mount Etna, evidencing that their origin cannot be related to a univocal process. Although classic fractional crystallization of the basic magmas feeding the Etnean system cannot be ruled out from the evolutionary processes, in this paper, we numerically demonstrated that gas-induced partial melting of the crystallized trachybasaltic rocks of the dykes beneath the volcano edifice can be considered as an alternative way to obtain trachyandesitic magmas (Figure 9). Major element mass balance models, supported by simulations performed by trace elements (see Supplementary Materials, Tables S2-S5), showed that Mount Etna trachyandesites could be produced either after ca. $55 \% \mathrm{FC}$ of a starting trachybasaltic melt or by $\sim 20-40 \%$ gas-induced partial melting of the host mugearitic rocks filling the conduits (Figure 9). This process would be particularly efficient at Mount Etna, whose feeding system is characterized by a high persistent gas flux that can be assumed as being higher during the Ellittico stage, as testified by field evidence. In fact, the qualitative and quantitative 3D studies of texture and bubbles of the lavas outcropping in the investigated sequence point out that gas content of the erupted melts was significantly higher than the present day, leading to the eruption of high-vesiculated lavas (up to foamy appearance), showing also evidence of turbulent transport resulted in the banded textures.

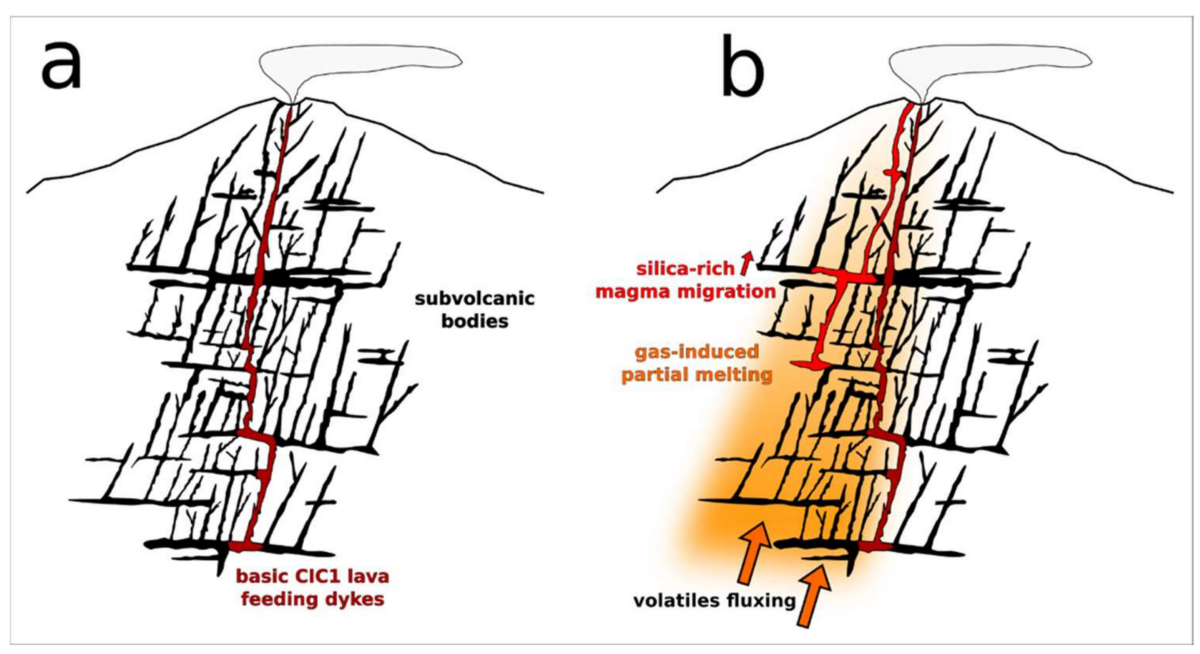

Figure 9. Schematic 2D view (not in scale) of the Etnean feeding system, constituted by crystallized subvolcanic bodies; (a) "classic" migration path of Etnean magmas feeding basic (CIC1) eruptions and (b) volatiles fluxing triggering the gas-induced partial melting producing more evolved melts (TR magmas).

The magma genesis and eruptive process described in this paper establish a novel and unexplored interpretative path for the understanding of the process acting in complex, gas-rich volcanic systems such as Mount Etna. We believe that this approach can explain some of the most intriguing issues that still feed the debate on the role of gases in volcanic 
systems and, in an ampler way, in the comprehension of the real nature and mechanisms of volcanic complex systems.

Supplementary Materials: The following are available online at https:/ / www.mdpi.com/2075-163 X/11/3/333/s1, Table S1: Mineral chemistry, Table S2: Results of fractional crystallization, Table S3: Kd used for fractional crystallization, Table S4: Results of partial melting, Table S5: Kd used for partial melting.

Author Contributions: Conceptualization, C.F. and G.L.; fieldwork, C.F. and G.L.; methodology, C.F., G.L., F.C., and P.P.G.; software, G.L.; validation, G.L., F.C., and P.P.G.; formal analysis, G.L., F.C. and P.P.G.; data curation, G.L., F.C., and P.P.G.; writing—original draft preparation, C.F., G.L., F.C., and P.P.G.; writing-review and editing, C.F. and M.C.; supervision, C.F. and M.C. All authors have read and agreed to the published version of the manuscript.

Funding: This research received no external funding.

Institutional Review Board Statement: Not applicable.

Informed Consent Statement: Not applicable.

Data Availability Statement: Data supporting reported results can be found in the Supplementary Materials.

Acknowledgments: The authors wish to thank Lucia Mancini from Elettra Sincrotrone Trieste for her precious help during the experiment of X-ray computed microtomography. The authors wish also to thank Editor Nikola Burazer and two anonymous reviewers for their thoughtful and constructive review.

Conflicts of Interest: The authors declare no conflict of interest.

\section{References}

1. Clocchiatti, R.; Condomines, M.; Guénot, N.; Tanguy, J.-C. Magma changes at Mount Etna: The 2001 and $2002-2003$ eruptions. Earth Planet. Sci. Lett. 2004, 226, 397-414. [CrossRef]

2. Métrich, N.; Allard, P.; Spilliaert, N.; Andronico, D.; Burton, M. 2001 flank eruption of the alkali- and volatile-rich primitive basalt responsible for Mount Etna's evolution in the last three decades. Earth Planet. Sci. Lett. 2004, 228, 1-17. [CrossRef]

3. Spilliaert, N.; Allard, P.; Métrich, N.; Sobolev, A.V. Melt inclusion record of the conditions of ascent, degassing, and extrusion of volatile-rich alkali basalt during the powerful 2002 flank eruption of Mount Etna (Italy). J. Geophys. Res. Space Phys. 2006, 111, 04203. [CrossRef]

4. Spilliaert, N.; Metrich, N.; Allard, P. S-Cl-F degassing pattern of water-rich alkali basalt: Modelling and relationship with eruption styles on Mount Etna volcano. Earth Planet. Sci. Lett. 2006, 248, 772-786. [CrossRef]

5. Ferlito, C.; Viccaro, M.; Cristofolini, R. Volatile-induced magma differentiation in the plumbing system of Mt. Etna volcano (Italy): Evidence from glass in tephra of the 2001 eruption. Bull. Volcanol. 2008, 70, 455-473. [CrossRef]

6. Ferlito, C.; Coltorti, M.; Cristofolini, R.; Giacomoni, P.P. The contemporaneous emission of low-K and high-K trachybasalts and the role of the NE Rift during the 2002 eruptive event, Mt. Etna, Italy. Bull. Volcanol. 2008, 71, 575-587. [CrossRef]

7. Ferlito, C.; Lanzafame, G. The role of supercritical fluids in the potassium enrichment of magmas at Mount Etna volcano (Italy). Lithos 2010, 119, 642-650. [CrossRef]

8. Giacomoni, P.; Coltorti, M.; Mollo, S.; Ferlito, C.; Braiato, M.; Scarlato, P. The 2011-2012 paroxysmal eruptions at Mt. Etna volcano: Insights on the vertically zoned plumbing system. J. Volcanol. Geotherm. Res. 2018, 349, 370-391. [CrossRef]

9. Viccaro, M.; Ferlito, C.; Cortesogno, L.; Cristofolini, R.; Gaggero, L. Magma mixing during the 2001 event at Mount Etna (Italy): Effects on the eruptive dynamics. J. Volcanol. Geotherm. Res. 2006, 149, 139-159. [CrossRef]

10. Giacomoni, P.P.; Ferlito, C.; Alesci, G.; Coltorti, M.; Monaco, C.; Viccaro, M.; Cristofolini, R. A common feeding system of the NE and S Rifts as revealed by the bilateral 2002/2003 eruptive event at Mt. Etna (Sicily, Italy). Bull. Volcanol. 2012, 74, $2415-2433$. [CrossRef]

11. Monaco, C.; Catalano, S.; Cocina, O.; De Guidi, G.; Ferlito, C.; Gresta, S.; Musumeci, C.; Tortorici, L. Tectonic control on the eruptive dynamics at Mt. Etna Volcano (Sicily) during the 2001 and 2002-2003 eruptions. J. Volcanol. Geotherm. Res. 2005, 144, 211-233. [CrossRef]

12. Caltabiano, T.; Burton, M.; Giammanco, S.; Allard, P.; Bruno, N.; Murè, F.; Romano, R. Volcanic gas emission from the summit craters and flanks of Mt. Etna, 1987-2000. In Mt. Etna: Volcano Laboratory, Geophysical Monograph Series AGU; Calvari, S., Bonaccorso, A., Coltelli, M., Del Negro, C., Falsaperla, S., Eds.; Wiley: Hoboken, NJ, USA, 2004; Volume 143, pp. 111-128.

13. Mollo, S.; Giacomoni, P.P.; Andronico, D.; Scarlato, P. Clinopyroxene and titanomagnetite cation redistributions at Mt. Etna volcano (Sicily, Italy): Footprints of the final solidification history of lava fountains and lava flows. Chem. Geol. 2015, $406,45-54$. [CrossRef] 
14. Mollo, S.; Giacomoni, P.P.; Coltorti, M.; Ferlito, C.; Iezzi, G.; Scarlato, P. Reconstruction of magmatic variables governing recent Etnean eruptions: Constraints from mineral chemistry and P-T-fO2-H2O modelling. Lithos 2015, 212-215, 311-320. [CrossRef]

15. Corsaro, R.A.; Cristofolini, R. Nuovi dati petrochimici ed isotopici sulla successione del Mongibello Recente (M.te Etna). Boll. Acc. Gioenia Sci. Nat. 1993, 26, 185-225.

16. Joron, J.L.; Treuil, M. Etude géochimique et pétrogenése des laves e l'Etna, Sicilie, Italie. Bull. Volcanol. 1984, 47, 1125-1144. [CrossRef]

17. Armienti, P.; Innocenti, F.; Petrini, R.; Pompilio, M.; Villari, L. Sub-aphyric alkali basalt from Mt. Etna: Inferences on the depth and composition of the source magma. Rend. Soc. It. Mineral. Petrol. 1988, 43, 877-891.

18. Tanguy, J.-C.; Condomines, M.; Kieffer, G. Evolution of the Mount Etna magma: Constraints on the present feeding system and eruptive mechanism. J. Volcanol. Geotherm. Res. 1997, 75, 221-250. [CrossRef]

19. Tanguy, J.-C.; Condomines, M.; Le Goff, M.; Chillemi, V.; La Delfa, S.; Patanè, G. Mount Etna eruptions of the last 2,750 years: Revised chronology and location through archeomagnetic and 226Ra-230Th dating. Bull. Volcanol. 2007, 70, 55-83. [CrossRef]

20. Branca, S.; Ferrara, V. The morphostructural setting of Mount Etna sedimentary basement (Italy): Implications for the geometry and volume of the volcano and its flank instability. Tectonophysics 2013, 586, 46-64. [CrossRef]

21. Ferlito, C.; Cristofolini, R. Geologia dell'area sommitale dell'Etna. Boll. Acc. Gioenia Sci. Nat. Catania 1989, 22, 357-380.

22. Branca, S.; Coltelli, M.; Groppelli, G.; Bonaccorso, A.; Calvari, S.; Del Negro, C.; Falsaperla, S. Geological evolution of Etna volcano. In Extreme Events; American Geophysical Union (AGU): Washington, DC, USA, 2004; Volume 143, pp. 49-63.

23. Coltelli, M.; Del Carlo, P.; Vezzoli, L. Stratigraphic constraints for explosive activity in the past 100 ka at Etna Volcano, Italy. Acta Diabetol. 2000, 89, 665-677. [CrossRef]

24. Condomines, M.; Kieffer, G.; Allegre, C.J. Magmatic evolution of a volcano studied by the Th/U disequilibrium and trace ele-ment systematic: The Etna case. Geochim. Cosmochim. Acta 1982, 46, 1397-1416. [CrossRef]

25. Ferlito, C.; Cristofolini, R. Evidenze di corpi subvulcanici poco profondi nella successione Etnea lungo le pareti occidentali della valle del bove. Mem. Soc. Geol. Ital. 1991, 47, 485-493.

26. Ferlito, C. Geologia e Petrologia Delle Successioni di Vulcaniti Affioranti Nella Parte Sud-Occidentale Della Valle del Bove (Etna). Ph.D. Thesis, University of Catania, Catania, Italy, 1994.

27. Lanzafame, G.; Mollo, S.; Iezzi, G.; Ferlito, C.; Ventura, G. Unravelling the solidification path of pahoehoe "cicirara" lava from Mount Etna volcano. Bull. Volcanol. 2013, 75, 703-719. [CrossRef]

28. Germanique, J. Major, trace and rare-earth elements in fourteen gsj reference samples. Determination by $\mathrm{x}$-ray fluorescence spectrometry and inductively coupled plasma optical emission spectrometry. Geostand. Geoanalytical. Res. 1994, 18, 91-100. [CrossRef]

29. Franzini, M.; Leoni, L. A full matrix correction in X-ray fluorescence analysis of rock samples. Atti Soc. Tosc. Sci. Nat. 1972, 79, 7-22.

30. Polacci, M.; Mancini, L.; Baker, D.R. The contribution of synchrotron X-ray computed microtomography to understanding volcanic processes. J. Synchrotron Radiat. 2010, 17, 215-221. [CrossRef]

31. Maire, E.; Withers, P.J. Quantitative X-ray to mography. Int. Mathem. Rev. 2014, 59, 1-43. [CrossRef]

32. Brun, F.; Pacile, S.; Accardo, A.; Kourousias, G.; Dreossi, D.; Mancini, L.; Tromba, G.; Pugliese, R. Enhanced and Flexible Software Tools for X-ray Computed Tomography at the Italian Synchrotron Radiation Facility Elettra. Fundam. Inform. 2015, 141, 233-243. [CrossRef]

33. Brun, F.; Mancini, L.; Kasae, P.; Favretto, S.; Dreossi, D.; Tromba, G. Pore3D: A software library for quantitative analysis of porous media. Nucl. Instrum. Methods Phys. Res. Sect. A Accel. Spectrometers Detect. Assoc. Equip. 2010, 615, 326-332. [CrossRef]

34. Al-Raoush, R.; Papadopoulos, A. Representative elementary volume analysis of porous media using X-ray computed tomog-raphy. Powder Technol. 2010, 200, 69-77. [CrossRef]

35. Otsu, N. A threshold selection method from gray-level histograms. IEEE Trans. Syst. Man Cybern. 1979, 9, 62-66. [CrossRef]

36. Lee, T.C.; Kashyap, R.L.; Chu, C.N. Building skeleton models via 3D medial surface axis thinning algorithms. CVGIP Grap. Mod. Im. Proc. 1994, 56, 462-478. [CrossRef]

37. Lanzafame, G.; Casetta, F.; Giacomoni, P.P.; Donato, S.; Mancini, L.; Coltorti, M.; Ntaflos, T.; Ferlito, C. The Skaros effusive sequence at Santorini (Greece): Petrological and geochemical constraints on an interplinian cycle. Lithos 2020, 362, 105504. [CrossRef]

38. Di Renzo, V.; Corsaro, R.; Miraglia, L.; Pompilio, M.; Civetta, L. Long and short-term magma differentiation at Mt. Etna as revealed by Sr-Nd isotopes and geochemical data. Earth Sci. Rev. 2019, 190, 112-130. [CrossRef]

39. Giacomoni, P.P.; Ferlito, C.; Coltorti, M.; Bonadiman, C.; Lanzafame, G. Plagioclase as archive of magma ascent dynamics on "open conduit" volcanoes: The 2001-2006 eruptive period at Mt. Etna. Earth Sci. Rev. 2014, 138, 371-393. [CrossRef]

40. Gennaro, E.; Iacono-Marziano, G.; Paonita, A.; Rotolo, S.G.; Martel, C.; Rizzo, A.L.; Pichavant, M.; Liotta, M. Melt inclusions track melt evolution and degassing of Etnean magmas in the last $15 \mathrm{ka}$. Lithos 2019, 324-325, 716-732. [CrossRef]

41. Casetta, F.; Coltorti, M.; Marrocchino, E. Petrological evolution of the Middle Triassic Predazzo Intrusive Complex, Italian Alps. Int. Geol. Rev. 2018, 60, 977-997. [CrossRef]

42. Shaw, D.M. Trace element fractionation during anatexis. Geochim. Cosmochim. Acta 1970, 34, 237-243. [CrossRef] 
43. Casetta, F.; Ickert, R.B.; Mark, D.F.; Bonadiman, C.; Giacomoni, P.P.; Ntaflos, T.; Coltorti, M. The Alkaline Lamprophyres of the Dolomitic Area (Southern Alps, Italy): Markers of the Late Triassic Change from Orogenic-like to Anorogenic Magmatism. J. Pet. 2019, 60, 1263-1298. [CrossRef]

44. Corsaro, R.A.; Rotolo, S.G.; Cocina, O.; Tumbarello, G. Cognate xenoliths in Mt. Etna lavas: Witnesses of the high-velocity body beneath the volcano. Bull. Volcanol. 2014, 76, 1-18. [CrossRef]

45. Casetta, F.; Ickert, R.; Mark, D.; Giacomoni, P.; Bonadiman, C.; Ntaflos, T.; Zanetti, A.; Coltorti, M. The Variscan subduction inheritance in the Southern Alps Sub-Continental Lithospheric Mantle: Clues from the Middle Triassic shoshonitic magmatism of the Dolomites (NE Italy). Lithos 2021, 380-381, 105856. [CrossRef]

46. Sharp, A.D.L.; Davis, P.M.; Gray, F. A low velocity zone beneath Mount Etna and magma storage. Nat. Cell Biol. 1980, 287, 587-591. [CrossRef]

47. Murru, M.; Montuori, C.; Wyss, M.; Privitera, E. The locations of magma chambers at Mt. Etna, Italy, mapped byb-values. Geophys. Res. Lett. 1999, 26, 2553-2556. [CrossRef]

48. Chiarabba, C.; De Gori, P.; Patané, D. Mt. Etna: Volcano Laboratory. In Geophysical Monograph Series; Bonaccorso, A., Calvari, S., Coltelli, M., Del Negro, C., Falsaperla, S., Eds.; American Geophysical Union: Washington, DC, USA, 2004; pp. $191-204$.

49. Patanè, D.; De Gori, P.; Chiarabba, C.; Bonaccorso, A. Magma Ascent and the Pressurization of Mount Etna's Volcanic System. Science 2003, 299, 2061-2063. [CrossRef]

50. Casetta, F.; Giacomoni, P.P.; Ferlito, C.; Bonadiman, C.; Coltorti, M. The evolution of the mantle source beneath Mt. Etna (Sicily, Italy): From the $600 \mathrm{ka}$ tholeiites to the recent trachybasaltic magmas. Intern. Geol. Rev. 2020, 62, 338-359. [CrossRef]

51. Ferlito, C. Mount Etna volcano (Italy). Just a giant hot spring! Earth Sci. Rev. 2018, 177, 14-23. [CrossRef]

52. Sharapov, V.; Mazurov, M.; Tomilenko, A.; Faleev, V. Mass transfer in garnet ultramafic xenoliths subject to partial melting under hot reduced gas flows. Russ. Geol. Geophys. 2011, 52, 165-177. [CrossRef]

53. Vona, A.; Di Piazza, A.; Nicotra, E.; Romano, C.; Viccaro, M.; Giordano, G. The complex rheology of megacryst-rich magmas: The case of the mugearitica "cicirara" lavas of Mt. Etna volcano. Chem. Geol. 2017, 458, 48-67. [CrossRef]

54. Kerr, R.C. Thermal erosion by laminar lava flows. J. Geophys. Res. Space Phys. 2001, 106, 26453-26465. [CrossRef]

55. Ferlito, C.; Siewert, J. Lava Channel Formation during the 2001 Eruption on Mount Etna: Evidence for Mechanical Erosion. Phys. Rev. Lett. 2006, 96, 028501. [CrossRef] [PubMed]

56. Pleše, P.; Higgins, M.D.; Baker, D.R.; Lanzafame, G.; Prašek, M.K.; Mancini, L.; Rooyakkers, S.M. Production and detachment of oxide crystal shells on bubble walls during experimental vesiculation of andesitic magmas. Contrib. Miner. Pet. 2019, 174, 21. [CrossRef]

57. Lanzafame, G.; Iezzi, G.; Mollo, S.; Ferlito, C.; Mancini, L.; Lezzi, F. Solidification and Turbulence (Non-laminar) during Magma Ascent: Insights from 2D and 3D Analyses of Bubbles and Minerals in an Etnean Dyke. J. Pet. 2017, 58, 1511-1533. [CrossRef] 